\title{
Consolidated Incineration Facility Tritium Emissions Monitoring
}

by

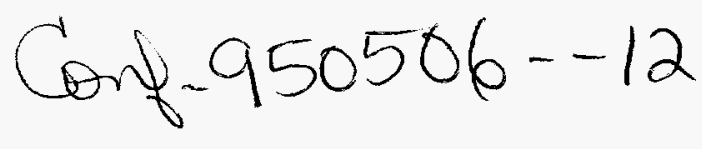

D. L. Dunn

Westinghouse Savannah River Company

Savannah River Site

Aiken, South Carolina 29808

J. R. Aggus

A document prepared for JOURNAL OF FUSION TECHNOLOGY 5TH TOPICAL MEETING ON TRITIUM TECHNOLOGY at Lake Maggiore from 05/28/95 - 06/03/95.

DOE Contract No. DE-AC09-89SR18035

This paper was prepared in connection with work done under the above contract number with the U. S. Department of Energy. By acceptance of this paper, the publisher and/or recipient acknowledges the U.S. Government's right to retain a nonexclusive, royalty-free license in and to any copyright covering this paper, along with the right to reproduce and to authorize others to reproduce all or part of the copyrighted paper. 


\section{DISCLAMMER}

This report was prepared as an account of work sponsored by an agency of the United States Government. Neither the United States Government nor any agency thereof, nor any of their employees, makes any warranty, express or implied, or assumes any legal liability or responsibility for the accuracy, completeness, or usefulness of any information, apparatus, product, or process disclosed, or represents that its use would not infringe privately owned rights. Reference herein to any specific commercial product, process, or service by trade name, trademark, manufacturer, or otherwise does not necessarily constitute or imply its endorsement, recommendation, or favoring by the United States Government or any agency thereof. The views and opinions of authors expressed herein do not necessarily state or reflect those of the United States Government or any agency thereof.

This report has been reproduced directly from the best available copy.

Available to DOE and DOE contractors from the Office of Scientific and Technical Information, P.O. Box 62, Oak Ridge, TN 37831; prices available from (615) 576-8401.

Available to the public from the National Technical Information Service, U.S. Department of Commerce, 5285 Port Royal Road, Springfield, VA 22161. 


\section{DISCLAIMER}

Portions of this document may be illegible in electronic image products. Images are produced from the best available original document. 


\title{
CONSOLIDATED INCINERATION FACILITY TRITIUM EMISSIONS MONTTORING
}

\author{
D. L. Dunn \\ Westinghouse Savannah River Company \\ Savannah River Technology Center \\ Aiken, South Carolina 29808 \\ (803) 725-1166
}

\begin{abstract}
The Savannah River Technology Center (SRTC), a research and development facility at the U. S. Department of Energy's Savannah River Site (SRS), provides environmental and regulatory compliance support to onsite operations. A new Consolidated Incinerator Facility (CIF) at SRS is being built to treat hazardous and a combination of hazardous and radioactive (mixed) wastes.
\end{abstract}

\section{INTRODUCTION}

The general operation and maintenance of the CIF during the handling of tritium-associated hazardous and mixed wastes will generate tritium oxide effluents. The CIF waste acceptance criteria were developed to administratively control the quantity and type of radioactive emissions. Tritium oxide emissions are limited to less than $1200 \mathrm{Ci} /$ year.

SRTC has developed a sampling system and analysis protocol that is in accordance with the United. States Environmental Protection Agency Code of Federal Regulations ( 40 CFR 61) and the National Emission Standards for Hazardous Air Pollutants (NESHAP) regulations. The SRTC NESHAP sampling protocol for the CIF will provide source-term data from all discharge points. The data will be evaluated to determine offsite dosage attributable to the facility. When sufficient evidence exists to confirm that the annual emissions are below the administratively controlled limit, sampling frequency will be reduced.

\section{DESCRIPTION}

The SRS CIF will process both liquid and solid waste. The facility objective will be to reduce the volume of solid and liquid combustible wastes by incineration. Incinerated wastes are those defined as hazardous or mixed under the South Carolina Hazardous Waste Man- agement Regulations or those contaminated with low-level, beta-gamma radioactivity.

The incineration system consists of a primary incineration chamber for solid and most liquid wastes with a secondary combustion chamber for the liquid wastes. The residence time of combustible solid material in the primary chamber is between 30 and 90 minutes. The secondary combustion chamber has a minimum gaseous residence time of two seconds downstream of the secondary combustion chamber burners.

The offgas system consists of a quench system for temperature reduction, a scrubber, a separator, mist eliminator, reheater, high efficiency particulate air (HEPA) filters, induced draft fans, and an exhaust stack. The quench system uses a caustic to aid in acid removal and to maintain a constant pH in the stack discharge.

The quantity and type of radioactive and chemical hazards present at the CIF are administratively controlled by waste acceptance criteria. The waste acceptance criteria specifiy the limits for radioactive materials entering the CIF and design and regulatory limits specify the limits for effluents at the CIF stack discharge points.

All solid wastes are prepackaged in combustible containers before delivery to the CIF. Solid waste arriving at the CIF is unloaded directly onto the conveyor in the box handling system. The conveyer moves each box through the portal monitor, weigh scale, and $x$-ray and assay stations, all of which provide indications of acceptability of the box of waste. Typical solid wastes are low-level, betagamma contaminated materials such as rags, wipes, cotton and rubber gloves, plastic suits, and footwear.

Liquid wastes are pumped to the CIF or transported in portable tanks and tank trucks. The CIF tank farm provides temporary storage for liquid waste. High-heat-value 
liquid wastes have a heat of combustion greater than 7500 Btu/lb. These high-heat-value liquid wastes include spent paint solvents, nonchlorinated organics, chlorinated organics and tritium-contaminated oils. Tritium contamination levels range from 0 to $500 \mathrm{nCi} / \mathrm{mL}$. Low-heat-value liquid wastes, with a heat of combustion less than $7500 \mathrm{Btu} / \mathrm{lb}$, are primarily aqueous wastes. Aqueous waste is contaminated water that comes from the CIF tank farm sumps, CIF process-line flushing, and other onsite facilities.

Blending liquid wastes is necessary to obtain a homogeneous feed for incineration with the desired combustion characteristics. After the wastes are blended, analyses are performed to determine the following properties; heat value, organic chlorine content, and ash content.

The offgas flow from the incineration process and from the main building exhaust is contained and passes through HEPA filters before being discharged through the stack. The isokinetic sampling points are located in the ductwork before their respective connections to the stacks. Differential pressure across the HEPA filters is provided to the control room as an indication of filter loading. The offgas flow is monitored for $\mathrm{CO}$ and $\mathrm{O}_{2}$, which are indicators of proper combustion. Monitoring is accomplished by redundant extractive gas sampling systems.

A side stream is taken from each of the isokinetic sampling system to collect tritium in the process/ventilation stream. The tritium sampling system consists of at least two modules, a power supply/control module and one or more collection canister modules.

The system is self-contained and operates with little operator assistance. The power supply/control module utilizes local AC power for the system. In the event of a Iocal AC power outage, the power supply/control module draws DC power from the CIF uninterruptible power supply (UPS) to maintain continuous operation. The power supply/control module includes a pump and motor and control logic circuitry to support the sampling functions. Control logic is communicated to the collection canister module with a RS232 interconnect cable.

The collection canister module consists of a series of seven sampling cells filled with Davison(s) type 4A molecular sieve designed to trap and retain atmospheric moisture. Other hardware contained in the unit includes the solenoid valves that isolate the sampling cells and a memory module that is used to store sampling parameters as supplied by the power supply/control module and the CIF control room.

\section{PROCEDURES}

Dry molecular sieve is verified by adding an accurately known weight of water to the sieve and then quantitatively recovering the water as part of a certification drying process. The weight of the recovered water must be within $5 \%$ of the water added. If it is not within $5 \%$, the sieve is rejected and is not loaded into the collection canister modules for sample collection.

Molecular sieve in the collection canister module adsorbs water vapor from the sampled air stream. The power supply/control module maintains a $1.04 \mathrm{~L} / \mathrm{min}$ sampling rate by means of a mass flow controller. The flow rate through the sampler and the flow rate through the stack will be continuously recorded in a memary storage unit on the collection canister module. Two collection canister mod-' ules are connected to the power supply/control module at all times. At the end of a seven-day (168 hour) sampling cycle, the control logic automatically switches the sampling flow from one collection canister module to the other collection canister module. This feature provides continuous sampling and a long window of opportunity to changeout the used collection canister module. The used collection canister module is replaced each week:

The collection canister modules will be returned to the laboratory where the sieve material will be unloaded into clean, dry sample-specific glass vessels. These vessels, which contain sieve material with physically adsorbed sample, will be transferred to a furnace connected to a vacuum manifold and evacuated to $\mathbf{5 0 0}$ microns. The furnace temperature will be raised slowly from an initial $300^{\circ} \mathrm{C}$ to $500^{\circ} \mathrm{C}$ and held constant at the higher temperature for 24 hours. The entrained water sample slowly desorbs and is crystallized onto the surface of a cold trap downstream of the furnace. The cold trap is maintained at $-40^{\circ} \mathrm{C}$ or colder.

After 24 hours, the freeze traps will be removed, capped, and allowed to warm to room temperature. Recovered sample water weights will be recorded, and the sample will be transferred to sample vials.

A three-gram aliquot of the recovered sample will be diluted into a scintillation vial containing liquid scintillation cocktail mix. The tritium concentration will be determined by measuring the tritium activity in the aliquot using a Tri-Carb 2000 CAMLL liquid scintillation analyzer. The analyzer will be calibrated as needed with National Institute of Standards and Technology (NIST) and NIST- traceable standards. Appropriate calibration standards and blanks will be analyzed with each suite of samples to verify calibrations and background. 


\section{SUMMARY}

To verify compliance with existing regulations and to provide process monitoring and control, facilities such as the CIF continue to rely on field-hardened batch sampling and laboratory analyses for tritium.

The integral placement of tritium samplers at discharge points in the CIF process should improve the efficiency of the operation and alert personnel to process upsets. Installed at the offgas discharge points, the data available from analyzed samples will provide CIF operations personnel with timely tritium release rates. With the known occurrence of any process upset, suspect tritium release rates will be available to CIF operations within 24 hours of a request for analysis. Tritium release rate data will be used to mitigate the consequences of exceeding the annual limits as set by state and federal regulations. Waste blend mixtures for tritium- contaminated wastes will be administratively controlled to meet the annual tritium release limits as established in the CIF NESHAP permit.

\section{ACKNOWLEDGMENT}

The information in this article was prepared during the course of work done under Contract No. DE-AC0989SR18035 with the U. S. Department of Energy.

\section{REFERENCES}

1. Safety Analysis Report - 200 H-Area, Savannah River Site, Consolidated Incineration Facility, WSRC-SA-17, Westinghouse Savannah River Company, Savannah River Technology Center, Aiken, South Carolina (December 1993).

2. Resource Conservation and Recovery Act (RCRA) Permit Application for the Consolidated Incineration Facility. Rev. 4, Westinghouse Savannah River Company, Savannah River Site, Aiken, South Carolina (July 1991). 